\title{
The effect of takeovers on the fundamental value of acquirers
}

\author{
Paul M. Guest ${ }^{\mathrm{a}}$, Magnus Bild ${ }^{\mathrm{b}}$, and Mikael Runsten ${ }^{\mathrm{c}}$ \\ ${ }^{\text {a }}$ Cranfield School of Management, Cranfield University \\ ${ }^{b, c}$ Stockholm School of Economics, Stockholm, Sweden
}

\begin{abstract}
This paper develops a new methodology to examine the financial impact of acquisitions, designed to address whether takeovers yield a positive net present value for the acquiring company. Specifically, we employ the residual income valuation method to compare the fundamental value of the acquiring company before acquisition with the fundamental value after acquisition. We apply this methodology to 303 UK acquisitions completed during 1985-96, and compare the results with the effects of takeover on profitability and short and long run share returns. We find that the impact of acquisition on fundamental value is slightly negative but statistically insignificant. This result differs from the effect of takeover on profitability, which is significantly positive, and the effect of takeover on share returns, which is significantly negative.
\end{abstract}

Keywords: acquisitions, fundamental value, residual income, profitability, share returns

Acknowledgements: We are grateful to two anonymous referees, the Editor (Pauline Weetman), Robin Chatterjee, Robert Conn, Andy Cosh, Alan Hughes and Sudi Sudarsanam for insightful and helpful comments. 


\section{Introduction}

From the perspective of acquiring firms, a question of paramount importance is whether the present value of the financial benefits from an acquisition are greater than the present value of the costs. In other words, is the acquisition a positive net present value investment? If it is, then the fundamental value of the acquiring firm should increase following acquisition, hence creating value for acquirer shareholders. According to financial theory, this is a key criterion that acquirers should apply and, apparently, a method that many finance executives of acquiring companies do apply (Graham and Harvey, 2001).

There is a vast research literature on the financial effects of takeover, which has primarily employed two distinct methodologies. Profitability studies compare the post-acquisition performance of the acquiring firm with the pre-acquisition performance of the acquiring and acquired firm. Share return event studies examine the share price impact of the acquisition on the acquired and acquiring firms. In addressing the specific question of whether the acquisition is a positive net present value investment and increases the fundamental value of the acquirer, both methods have drawbacks. Profitability studies are not designed to address this question and hence do not account for crucial aspects such as the timing of profits earned, or the amount paid for the target company. Share return studies examine the impact of an acquisition on the acquirer's share price at announcement, but the impact on share price may be very different from the impact on fundamental value. For example, an acquisition may be a positive net present value investment but not to the extent that the market expected, and hence share price may fall despite the acquirer's fundamental value increasing.

In this paper we develop an alternative methodology to address the impact of acquisitions on the fundamental value of acquirers, and test it on a sample of acquiring firms. Our approach is based on the residual income approach to fundamental valuation. In recent years, accounting research has reexplored fundamental approaches to corporate valuation and models based on residual income have attained a widespread use (e.g. Lee, 1999). We use the residual income approach to estimate the fundamental value of acquirers before acquisition and compare this valuation with their fundamental value following the acquisition. If takeovers create fundamental value for acquiring firms, then the 
latter should be greater than the former. Our approach provides an alternative methodology that avoids some of the weaknesses of profit and return studies in addressing this specific issue. However, it is important to note that it shares some weaknesses and has its own separate weaknesses, which we discuss below.

We apply the residual income methodology to a sample of 303 domestic UK acquisitions involving public companies. We compare the results of this approach with the effects of takeover on profitability and short and long run share returns. We find that the impact of acquisition on fundamental value is insignificantly negative. This result differs markedly from the effect of takeover on profitability, which is significantly positive, and the effect of takeover on share returns, which is significantly negative. Although acquirers improve their profitability, this does not result in a significant increase in fundamental value. The main contribution of this study is to use an established valuation technique to develop a new methodology for measuring the performance of acquiring firms.

The paper is organised as follows: The next section reviews the empirical literature on acquisition performance, and discusses why existing methods may not adequately measure the impact on fundamental value. Section 3 describes the sample, Section 4 describes the methodology, Section 5 reports the results from the empirical analysis and Section 6 concludes.

\section{Literature review}

In this section we consider what the existing empirical literature on acquisitions tells us about the effect of takeovers on fundamental value. In Section 2.1 we examine profitability studies and in Section 2.2 we consider the event study literature.

\subsection{Profitability studies}

The objective of profitability studies is to examine whether an acquisition improves the profitability of the combined assets of the acquirer and acquiree. The approach examines the difference between the post-acquisition performance of the acquirer (which includes the acquiree postacquisition) and the pre-acquisition combined (weighted average) performance of the acquirer and acquiree. It then compares this difference with a benchmark based on, for example, control firms 
matched by industry and size. The evidence for the UK appears to depend on the sample period. For studies covering the 1960s and 1970s, some studies (Meeks, 1977; Chatterjee and Meeks, 1996) find little evidence of improved profitability, whilst others (Cosh et al., 1980) find evidence of significant improvements. However, studies for the 1980s and 1990s consistently find evidence of significant improvements in performance (Chatterjee and Meeks, 1996; Manson et al., 1994; Manson et al., 2000; Powell and Stark, 2005 and Cosh et al., 2006). ${ }^{1}$

The methodology of profitability studies is not designed to address how takeovers impact the fundamental value of the acquirer, and thus it is difficult to infer this particular impact. There are several reasons for this.

First, in estimating the impact on fundamental value, the appropriate comparison is the fundamental value of the acquirer with the acquisition compared with the fundamental value of the acquirer without the acquisition. Profitability studies compare the acquirer's post-acquisition performance with the pre-acquisition weighted average performance of the acquirer and acquired companies. However, the pre-acquisition weighted average measure is not an appropriate benchmark for the acquirer's performance in the absence of the acquisition.

Second, the change in the acquirer's profits following an acquisition needs to be considered in relation to the acquirer's cost of capital. For fundamental value to be created, any marginal profit return must be greater than the marginal cost of capital. For example, the profitability of the acquirer could be lower following acquisition, but if the marginal profitability is higher than the marginal cost of capital, then the acquisition may create fundamental value.

Third, profitability studies give equal weight to each post-takeover year. However, the timing of profits is important in establishing whether acquisitions increase fundamental value, and future profits should be discounted by an appropriate cost of capital.

Finally, by explicitly excluding goodwill on acquisition from the acquirer's post-acquisition balance sheet and employing a pre-amortisation profit measure, profitability studies do not account for the price paid for the target company. The reason for this is that the objective of these studies is to compare the pre-acquisition combined performance with the post-acquisition combined performance,

1 For reviews, see Hughes (1989), Tuch and O’Sullivan (2007) and Martynova and Renneboog (2008). 
and including purchased goodwill would induce a downward bias to the profitability change. ${ }^{2}$ However, to examine the impact of takeover on fundamental value, this goodwill, which represents part of the cost of acquisition, must be taken into account. Alberts and Varaiya (1989) argue that given the large premiums that are typically paid, it is unlikely that the average acquisition creates fundamental value for the acquirer.

\subsection{Share return studies}

The majority of takeover event studies or share return studies examine share returns to the acquirer and acquiree over a short run period surrounding the announcement. Since these studies measure returns over very short time periods, compared to profitability studies they have the advantage of being less subject to problems of noise and benchmark error. The results show significant gains for target shareholders, zero to negative returns for acquiring shareholders, and significant gains overall. ${ }^{3}$ Two recent UK studies for the period under consideration in this paper report significantly negative abnormal returns to acquirers (Sudarsanam and Mahate, 2003 and Conn et al., 2005). The announcement returns have been interpreted as directly showing the impact on fundamental value of the acquisition, and hence showing that acquisitions are a zero or negative net present value investment for acquirers (see Bruner, 2002). A number of event studies also examine share returns over a long run post-acquistion period and find evidence of significant negative returns. ${ }^{4}$ These include UK studies that overlap our sample time period such as Gregory (1997), Sudarsanam and Mahate (2003) and Conn et al. (2005). One interpretation of long run negative returns is that they are evidence of initial market misvaluations of takeover gains, which reverse over the long run.

However, the share price reaction of the acquirer around the announcement and over the long run may not reflect the impact on the acquirer's fundamental value. The problem is that the announcement (and long run) returns reveal information not just about the potential synergies arising from the combination and how the value is split between the target and the bidder, but also the

2 A rare exception would be where the acquisition is paid for from the acquirer's cash reserves. In this case, removing goodwill would result in the combined assets being lower following acquisition, and therefore removal of goodwill will cause a positive bias to the impact of takeover on profitability.

3 For reviews, see Tuch and O'Sullivan (2007) and Martynova and Renneboog (2008).

4 For reviews, see Hughes (1989), Tuch and O'Sullivan (2007) and Martynova and Renneboog (2008). 
bidder's standalone value. It is seldom possible to disentangle the impact on stock prices of these effects and thereby evaluate whether the marginal benefit of the acquisition to the acquirer is greater than the cost.

One problem is anticipatory market prices. For example, when an acquirer makes a positive net present value acquisition, the market value of the firm will be affected, depending on whether the net present value meets expectations. If the market expects a firm to make high positive net present value acquisitions, market prices will build in this expectation, and even if the new acquisition has a positive net present value, share price may decline if the acquisition does not meet market expectations. ${ }^{5}$

Another problem is stock market mispricing. Acquisitions (especially those made with equity) may reveal to the market that acquirers are overvalued, and part of the announcement (and long run) return may reflect a negative reaction to perceived overvaluation rather than fundamental value destruction (Shleifer and Vishny, 2003). Ang and Cheng (2006) and Dong et al. (2006) provide evidence consistent with this. ${ }^{6}$

In summary, because of market expectations and stock market mispricing, event studies may not measure the impact of acquisitions on the fundamental value of the acquirer. Similarly, it is difficult to infer the impact of a takeover on fundamental value from profitability studies, since they do not measure the total discounted value effect of a takeover. For these reasons, we adopt a residual income valuation method as an alternative means of assessing the impact of an acquisition on the acquirer's fundamental value.

\section{The sample}

We examine a comprehensive sample of acquisitions of UK public companies by UK public companies, completed between January 1985 and December 1996. The acquisitions are drawn from the Thomson Financial publication Acquisitions Monthly. Takeovers are defined as occurring when

5 Jensen and Ruback (1983) report that returns tend to be much larger for acquisition programme announcements than for subsequent acquisition announcements, and argue that the impact of an acquisition on fundamental value may have been incorporated at the time of an acquisition programme announcement.

6 Bhagat et al. (2005) point to other 'revelation biases' that result in both accounting and event study returns providing a biased estimate of the fundamental gains from takeovers. For example, the fact of a bid may reveal prospects for future accounting improvements that would have occurred even without a takeover. Bhagat et al. (2005) and Hietala et al. (2003) use an interventionist approach to avoid such effects, and show that takeovers have a positive impact on acquirer returns. However, such approaches can only be applied to specific samples of acquisitions. 
the acquirer owns less than 50 percent of the target's shares before the takeover, and increases its ownership to at least 50 percent as a result of the takeover. We include takeovers for which Datastream holds both bidder and target accounting data for a minimum period of two years before and two years after the takeover. This results in an initial sample of 358 acquisitions. We exclude acquisitions in which either the acquirer, target or control firms have a negative equity book value in any of the four years before or following the acquisition, since our performance measures are nonsensical for such firms. This procedure results in a sample of 303 acquisitions.

Table 1 reports transaction characteristics for the 303 acquisitions. By method of payment, we classify $21.45 \%$ of the sample acquisitions as 'Cash', defined as either pure cash offers (13.53\%) or cash offers with a loan note alternative (7.92\%). The latter method was common during the sample period and allowed target shareholders to defer capital gains tax, but is, in economic reality, a cash offer. We classify $57.1 \%$ of acquisitions as 'Equity', defined as either pure equity offers $(21.78 \%)$ or equity offers with a cash alternative (35.31\%). 12.87\% of acquisitions involve a 'Mixed' offer, defined as a combination of cash and equity. We define the remaining $8.58 \%$ as 'Other'. 7

The average bid premium (measured as the final offer price minus the price one month before announcement) is $36.80 \%$. The average relative size of target to acquirer companies (in terms of market value) at the time of the acquisition is $35.72 \%$. A minority (34.98\%) of sample acquisitions involve two firms in the same Datastream Industrial Classification level four, and are classified as horizontal. $^{8}$ The majority (65\%) of acquisitions take place in the 1980 s. The 303 acquisitions are carried out by 205 acquiring firms, with 63 carrying out more than one sample acquisition.

\section{INSERT TABLE 1 ABOUT HERE}

\section{Methodology}

In this section we describe the methodology employed in the study. To place the results using our fundamental value approach in context, we also estimate takeover performance using an accounting

7 These include the following payment methods: all cash or cash plus equity $(2.97 \%)$, all equity or cash plus equity (2.31\%), convertible preference shares with a cash alternative $(0.33 \%)$, equity or debt or cash $(0.99 \%)$, all cash or cash plus equity with a loan note alternative $(0.66 \%)$, pure debt $(0.33 \%)$, and other $(0.99 \%)$.

8 This classification is based on 38 different industrial classifications and is similar in detail to the two-digit UK Standard Industrial Classification. 
rate of return measure and event study analysis. Section 4.1 describes the former, Section 4.2 the latter. Section 4.3 describes the fundamental valuation approach.

\subsection{Accounting rate of return methodology}

For the accounting rate of return measure we compare the post-takeover profitability of acquirers with the pre-takeover weighted average profitability of acquirers and targets, relative to non-merging control firms. The weighted average performance of the bidder and target firms is calculated over the three years before the takeover (years -3 to -1 ) to obtain the pre-takeover performance measure. We compare this with the three-year post-takeover performance (years 1 to 3 ) of the bidder to measure the performance change caused by the merger. The abnormal profit return is the difference between this change for the combined firm and the change for the weighted-average control firms. The weights for the control firms are the relative equity book values of bidders and targets in year -1 . Consistent with previous studies, we exclude year 0 , the year of consolidation, from the analysis. This is because with acquisition accounting, the consolidated profit and loss account of the acquirer in year 0 only shows the proportion of the target's profits earned since the date of acquisition. ${ }^{9}$ If acquirers die within the four post-takeover years, the year of death becomes the final year of analysis.

As the specific measure of profitability, we use a return on equity (ROE) measure, consisting of net income, scaled by the opening period book value of ordinary shareholders funds. ${ }^{10}$ We select this measure because it is most closely linked to the measure used in the residual income method described in Section 4.3 below.

To benchmark the change in profitability, we use non-merging control firms matched by industry and size. Previous acquisition studies show that acquirers tend to have above average size (Hughes, 1989), while acquisitions tend to cluster in specific industries that are undergoing fundamental shocks (for the US see Mitchell and Mulherin, 1996 and Andrade and Stafford, 2004, whilst for the UK see Powell and Yawson, 2005). Previous performance studies show that both factors can determine future

9 In separate tests, we include year 0 and therefore examine four years of post-acquisition data. The results are very similar and our conclusions unchanged.

10 In separate tests, we use an average of opening and closing book equity as the denominator. The results using this alternative method are very similar and our conclusions unchanged. 
profitability (Barber and Lyon, 1996). We select the control firms from all firms listed on Datastream that neither made, nor received, a takeover offer for a public company during the three years before and after the acquisition year and that have accounting data on Datastream over this period. We first match each sample firm to all non-merging firms in the same Datastream Industrial Classification level four, which is equivalent to Standard Industrial Classification Level 2. Second, we select the firm within this industrial code with book value of total assets closest to the sample firm's book value in the year prior to takeover. ${ }^{11}$

To measure takeover performance, we use a simple change model that compares pre- and postacquisition performance as follows:

Takeoverperformanc $=\mathrm{ROE}_{\text {post }}-\mathrm{ROE}_{\text {pre }}$

where $\mathrm{ROE}_{\text {post }}$ is the mean abnormal profit rate for the three post-takeover years, $\mathrm{ROE}_{\text {pre }}$ is the mean abnormal profit rate for the three pre-takeover years, and by abnormal, we mean the sample firm's ROE minus the control firm's ROE.

A potential problem with the change model in equation (1) is that if acquirers have above average pre-acquisition profitability, then profitability may decline following takeover because of mean reversion in profitability, regardless of any takeover impact. The studies referred to above show acquirers have above average pre-acquisition profitability. Rather than match on this additional factor, which would mean compromising on either the industry match or the size match, we employ the regression model employed by previous studies (Manson et al., 2000), regressing the post-takeover abnormal profit rate for each acquisition on an equivalent pre-takeover abnormal profit rate as follows:

$$
\mathrm{ROE}_{p o s t}=\alpha+\beta \mathrm{ROE}_{p r e}+\varepsilon
$$

The coefficient $\beta$ allows for mean reversion in profitability and the intercept $\alpha$ gives an estimate of the average improvement in performance. By controlling for pre-takeover performance in this way, the mean unexplained post-takeover performance (the intercept $\alpha$ ) is attributable to the takeover. ${ }^{12}$

11 The average (median) total asset size in the year prior to takeover for sample firms and their controls are as follows: acquirers, $£ 1,346.1 \mathrm{~m}(£ 194.1 \mathrm{~m})$; acquirer control firms, $£ 1,700.1 \mathrm{~m}(£ 144.4 \mathrm{~m})$; target firms, $£ 182.2 \mathrm{~m}$ (£29.4m); target control firms, $£ 323.0 \mathrm{~m}(£ 34.0 \mathrm{~m})$.

12 Although equation (2) controls for pre-bid profitability, it may produce biased results when acquirers differ from control firms on unmatched permanent characteristics that determine future profitability (Ghosh, 2001). In 
As noted in Section 2.1 above, if goodwill arises on acquisition and is capitalised on the acquirer's balance sheet, this may impose a downward bias on the profitability measure compared to the pretakeover combined performance benchmark. Hence previous studies have removed goodwill on acquisition from the acquirer's post-acquisition assets. Over our sample period, UK acquirers could account for an acquisition using either 'acquisition' or 'merger' accounting. Acquisition accounting involves consolidating the acquiree's assets at fair values, capitalising goodwill on the acquirer's balance sheet with amortisation. Merger accounting involves adding the acquirer's and acquiree's assets and liabilities together at book values without any goodwill. From the start of our sample period to 1998 , most UK acquirers used the acquisition method but then immediately wrote-off the purchased goodwill as they were allowed to do (Higson, 1998; Gregory, 2000). ${ }^{13}$ Capitalised goodwill (and hence any expected bias) is therefore expected to be negligible for the acquirers in our sample. ${ }^{14}$

For our 303 sample acquisitions, of the 182 sample acquisitions for which the Thomson Financial SDC Database reports the accounting method, in only one case does the acquirer use merger accounting. The vast majority of our sample acquirers also appear to write off goodwill immediately against reserves. Of the 303 acquirers, 269 have zero goodwill and intangible assets on their balance sheet at year 0 , and a further four report no change from year -1 to year 0 . Thus, at most 34 sample acquirers capitalise goodwill following the acquisition, though the figure may be less since the change could reflect other changes such as incorporated target goodwill, or the purchase or revaluation of other intangible assets. In what follows, for robustness, we report results for both the entire sample and for the reduced sample of 269 acquirers that do not capitalise goodwill on acquisition. We consider the robustness of our results in Section 5.1 below.

\subsection{Event study methodology}

such cases, the intercept picks up the effect of these factors on profitability and a simple change model as in equation (1) is more appropriate. However, if the matching method does not control for a temporary (rather than permanent) driver of profitability, then both models are equally biased (Ghosh, 2001).

13 Following FRS 10 in 1998, UK acquirers using acquisition accounting were no longer allowed to immediately write-off goodwill to reserves.

14 Higson (1998) shows that acquirers tended to write down the values of acquired assets below book values. The effect of this is to inflate goodwill on acquisition, and writing off this goodwill reduces equity book values, hence improving post-acquisition return on equity. This would cause an upward bias to the profitability results. 
We estimate abnormal share returns for both the announcement month, and the 36-month posttakeover period beginning the month following completion. In measuring post-takeover returns, we employ two measures, paying careful attention to the potential problem of cross-sectional dependence in returns. This is a potential problem for our sample because acquisitions tend to cluster by both time and industry (Mitchell and Mulherin, 1996), causing standard errors to be biased downwards and $t$ statistics to be biased upwards (Barber and Lyon, 1997; Fama, 1998; Lyon et al., 1999; Mitchell and Stafford, 2000)

Firstly, we estimate buy-and-hold abnormal returns (BHARs) and calculate $t$-statistics which are adjusted for cross-sectional dependence using the following approximation for the standard deviation (Mitchell and Stafford, 2000): $\sigma$ BHAR (independence) / $\sigma$ BHAR (dependence) $\approx 1 / \sqrt{ } 1+(N-1) \rho i, j$ where $\sigma \mathrm{BHAR}=$ standard deviation of individual BHARs, $N=$ number of sample acquisitions and $\rho i, j$ $=$ average correlation of individual BHARs. As an estimate for $\rho i, j$, we use the estimate of 0.002 calculated by Conn et al. (2005) for a larger sample of acquisitions over our sample period. ${ }^{15}$

Secondly, we use the Jaffe (1974) - Mandelker (1974) calendar time portfolio technique. In each calendar month we form a portfolio of event firms, and take the average cross-sectional abnormal return for that month. The average abnormal return for the entire sample is the time series average and the $t$-test is calculated using the time series standard deviation, which is not biased in the presence of cross-sectional dependence (Lyon et al., 1999).

The abnormal returns are estimated relative to the acquirer industry and size matched control firms described in Section 4.1 above. The control firm approach is preferred to a reference portfolio approach because it avoids both the skewness and rebalancing biases (see e.g., Barber and Lyon, 1997). The skewness bias occurs if the distribution of long run abnormal stock returns is skewed positively. The rebalancing bias occurs because the compound returns of a reference portfolio, such as a market index, are calculated assuming periodic rebalancing. As with the accounting rate of return methodolo-

15 Conn et al. (2005) calculate average pairwise correlations of annual BHARs for all acquirers that complete acquisitions in the same month, the grand average for which is 0.008 . They then assume that the average correlation for overlapping observations is linear in the number of months of calendar time overlap, ranging from zero for non-overlapping observations to the estimated average correlation of 0.008 for acquirers with complete overlap. 
gy, where acquirers die within the 36 post-takeover months, the month of death is the final month of evaluation. ${ }^{16}$

\subsection{Fundamental valuation methodology}

To measure the effect of takeover on fundamental value, we examine the difference between the pre-acquisition expected fundamental value of acquiring firms and the realised post-acquisition fundamental value. If acquisitions create fundamental value, then the difference should be positive. The valuation method we use to measure fundamental value is the residual income valuation (RIV) method (Preinreich, 1938; Edwards and Bell, 1961; Peasnell, 1982; Stark, 1986; Feltham and Ohlson, 1995; Ohlson, 1995). In this section, we present the basic RIV model and adapt it for our particular study.

\subsubsection{The RIV model}

The RIV model rests on three basic assumptions. First, fundamental value equals the present value of expected dividends:

$$
V_{t}=\sum_{i=1}^{\infty} \frac{E_{t}\left[D_{t+i}\right]}{\left(1+r_{e}\right)^{i}}
$$

where $V_{t}$ is the stock's fundamental valuation at time $t, E_{t}[\cdot]=$ expectation based on information available at time $t, D_{t+i}=$ dividends for period $t+i$, and $r_{e}=$ cost of equity capital.

Second, the clean surplus accounting relation states that all changes in the book value of equity pass through the income statement:

$$
B_{t}=B_{t-1}+\mathrm{NI}_{t}-D_{t}
$$

where $B_{t}=$ book value of equity at time $t$ and $\mathrm{NI}_{t}=$ net income for period $t$. This assumption allows dividends to be expressed in terms of future earnings and book values. Combining the clean surplus relation in equation (4) with equation (3) and rearranging yields:

16 In additional tests we instead replace the remaining acquirer missing months with the return for the control firm. The results using this alternative method are very similar. 


$$
V_{t}=B_{t}+\sum_{i=1}^{\infty} \frac{E_{t}\left[\mathrm{NI}_{t+i}-r_{e} \cdot B_{t+i-1}\right]}{\left(1+r_{e}\right)^{i}}-\frac{E_{t}\left[B_{t+\infty}\right]}{\left(1+r_{e}\right)^{\infty}}
$$

The final term in equation (5) is assumed to be zero. The second term is the present value of future residual income. Hence fundamental value equals the sum of book value and the present value of future residual income.

$$
V_{t}=B_{t}+\sum_{i=1}^{\infty} \frac{E_{t}\left[\left(\mathrm{NI}_{t+i}-r_{e} B_{t+i-1}\right]\right.}{\left(1+r_{e}\right)^{i}}
$$

Practical application of equation (6) necessitates a truncated forecast horizon with an assumption regarding the terminal value at the horizon. Over a finite horizon, the model can be modified to include a terminal value estimate as follows:

$$
V_{t}=B_{t}+\sum_{i=1}^{T} \frac{E_{t}\left[\left(\mathrm{NI}_{t+i}-r_{e} B_{t+i-1}\right]\right.}{\left(1+r_{e}\right)^{i}}+\frac{E_{t+T}\left[\left(\mathrm{NI}_{t+T}-r_{e} B_{t+T-1}\right]\right.}{\left(1+r_{e}\right)^{t+T-1} r_{e}}
$$

The second term on the right hand side of equation (7) represents abnormal earnings in the first $T$ periods and the third term represents the 'terminal value', measured as the abnormal earnings of period $t+T$, discounted in perpetuity assuming no further growth in $B$ after year $T$.

4.3.2. Adopting the RIV model to measure the impact of acquisition on the fundamental values of acquirers.

To measure the impact of an acquisition on the fundamental value of the acquiring firm, we calculate the realised fundamental value of the acquirer following the acquisition and compare this with the expected fundamental value of the acquirer prior to acquisition.

Equation (7) is our starting point for estimating the former. We choose a forecast horizon of four years of accounting performance following acquisition, in order to ensure consistency with the profitability and event study methodologies described above. Equation (7) is hence first modified as follows for the realised post-acquisition value of the acquirer:

$$
V_{p o s t}=B_{-1}+\frac{\mathrm{NI}_{0}-r_{e} \cdot \mathrm{B}_{-1}}{\left(1+r_{e}\right)}+\frac{\mathrm{NI}_{1}-r_{e} \cdot \mathrm{B}_{0}}{\left(1+r_{e}\right)^{2}}+\frac{\mathrm{NI}_{2}-r_{e} \cdot \mathrm{B}_{1}}{\left(1+r_{e}\right)^{3}}+\frac{\mathrm{NI}_{3}-r_{e} \cdot \mathrm{B}_{2}}{\left(1+r_{e}\right)^{3} r_{e}}
$$


The first term is book value in year -1 , the last accounting year before completion of the acquisition. Year 0 is the year of consolidation, the accounting year following the completion date of the acquisition. The second, third and fourth terms describe residual income in years 0,1 and 2. The fifth term describes the terminal value, which is the abnormal earnings of year 3 discounted in perpetuity.

Acquisitions often involve issuing shares to the acquired firm's shareholders as a method of payment. Issuing new shares can increase total fundamental value whilst reducing value per share, and therefore we must focus on the impact of an acquisition on the per share fundamental value rather than the overall fundamental value (Penman, 2007: 94). We therefore divide each term in equation (8) by the number of shares to get per share values as follows:

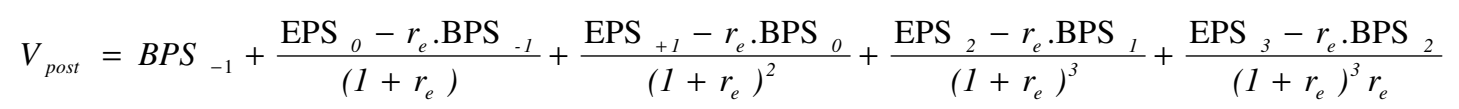

where BPS is book equity per share, and EPS is net income (earnings) per share. ${ }^{17}$

In the absence of any violations of clean surplus accounting, we can use equation (9) to estimate the realised fundamental value of the acquirer following the acquisition. However, in the case of acquisitions, there are potential violations of clean surplus accounting (discussed below) in year 0 , which impact book value in year 0 but do not pass through the income statement in year 0 . In order to avoid these dirty surplus effects in our estimate of post-acquisition fundamental value, rather than include book value from year -1 and residual income from year 0 [as in equation (9)], we replace these terms with book value and dividends from year 0 as follows: ${ }^{18}$

$V_{\text {post }}=\frac{\mathrm{DPS}_{0}}{\left(1+r_{e}\right)}+\frac{\mathrm{BPS}_{0}}{\left(1+r_{e}\right)}+\frac{\mathrm{EPS}_{1}-r_{e} \cdot \mathrm{BPS}_{0}}{\left(1+r_{e}\right)^{2}}+\frac{\mathrm{EPS}_{2}-r_{e} \cdot \mathrm{BPS}_{1}}{\left(1+r_{e}\right)^{3}}+\frac{\mathrm{EPS}_{3}-r_{e} \cdot \mathrm{BPS}_{2}}{\left(1+r_{e}\right)^{3} r_{e}}$

The first two terms are dividends per share (DPS) and book value per share (BPS) in year 0. The last three terms are the same as in equation (9). Equation (10) avoids dirty surplus effects because by year 0 , the dirty surplus effect on book value has already occurred. Therefore, any change in future residual income caused by the altered book value [i.e. cost of equity multiplied by book value, terms 3 , 4 and 5 in equation (9)] is offset by the altered book value in year 0 [term 2 in equation (10)]. Note

17 Other residual income studies also calculate fundamental value on a per share basis (e.g. Penman and Sougiannis, 1998).

18 See Penman (2007: 570) for a broad description of this approach. 
that equations (9) and (10) give identical valuations if there is no violation of clean surplus accounting in year $0 .{ }^{19}$

Let us first assume that cash, rather than shares, is used to pay for the acquisition. The first reason for dirty surplus accounting effects in acquisitions is the method of accounting used. While the acquisition method with goodwill capitalisation, with or without amortisation, creates no dirty surplus effect, immediate goodwill write-off (or merger accounting) violates clean surplus accounting in year 0 . However, neither method affects equation (10) because any change in book value in year 0 exactly offsets the corresponding change in discounted future earnings (Penman, 2004: 577-8). ${ }^{20}$ Thus, with equation (10), whether merger or acquisition accounting is used, goodwill is immediately written off or capitalised, or if capitalised, held with or without amortisation, leaves post-acquisition value unaffected. ${ }^{21}$ However, it should be noted that if goodwill is amortised, equation (10) is affected by whether the earnings per share figure used in the terminal value calculation includes the amortisation charge or not, because this calculation should be based on steady state earnings per share (i.e. with no amortisation). In practice, equation (10) can be adjusted by adding amortisation back to earnings per share and book value per share (Penman, 2001: 653-4). ${ }^{22}$

The second reason for dirty surplus accounting effects is the issue of shares to pay for the acquisition. So far we have assumed that the acquisition is paid for with cash and in this case only if goodwill is written off is there a dirty surplus effect. However, if instead the acquisition is funded by shares, there is always an increase in the book value of the acquirer that bypasses the income statement, and hence, irrespective of the accounting method used, there is always a dirty surplus accounting effect in year 0 . Compared to year -1 , from year 0 onwards the acquiring firm's shareholders now additionally own the book value of the target company and its future residual

19 This and the subsequent assertions in this section are shown numerically in a seperate document which is available from the first author on request.

20 In contrast, applying equation (9) to such cases results in an upwardly biased value (assuming goodwill is positive) because the lower book value results in a lower capital charge, increasing residual income.

21 For UK listed firms, violations of clean surplus accounting due to the accounting method used for acquisitions are no longer a concern since 2004. IFRS3 (IASB, 2004) banned the use of merger accounting for all EU listed firms, banning the use for any firms applying IFRS 3 who must instead use purchase accounting and hold goodwill with impairment. [Although FRS10 (ASB, 1998) banned the dirty-surplus immediate writeoff of goodwill with purchase accounting for UK firms, merger accounting was still allowed in the UK until IFRS3 and hence dirty surplus violations continued to some extent for UK listed firms between 1998 and 2004]. 22 Because only a small number of our sample acquirers capitalise goodwill, and hence potentially amortise, we address this potential bias by excluding such acquirers in our robustness tests in Section 5 below. 
income. In exchange, the acquiring firm's shareholders give the acquired firm's shareholders a share in the post-acquisition fundamental value of the acquirer. The size of this share, determined by the number of shares given to the acquired firm's shareholders, determines whether or not the acquisition creates value for the acquirer's pre-acquisition shareholders. Equation (10) incorporates both these impacts of the acquisition, because it measures fundamental value from year 0 onwards and does so on a per share basis. ${ }^{23}$ The number of shares issued to target shareholders can be a source of fundamental value creation or destruction for pre-acquisition shareholders. For example, the acquirer can create fundamental value by using an artificially low number of overvalued shares to pay for the acquisition. Equation (10) incorporates this gain to pre-acquisition acquirer shareholders. Alternatively, the acquirer can destroy fundamental value by issuing an artificially high number of undervalued shares to pay for the acquisition. Again, equation (10) incorporates this loss to pre-acquisition acquirer shareholders. Although in our discussion we focus on the two extremes of either all cash or all equity methods of payment, equation (10) covers all other alternatives such as a cash-share alternative. ${ }^{24}$

To estimate the forecast fundamental value prior to acquisition, we forecast the same measures (that are realised in equation (10)) in the year before acquisition (year -1 ), as follows:

$$
V_{p r e}=\frac{E_{-1}\left(\mathrm{DPS}_{0}\right)}{\left(1+r_{e}\right)}+\frac{E_{-1}\left(\mathrm{BPS}_{0}\right)}{\left(1+r_{e}\right)}+\frac{E_{-1}\left(\mathrm{EPS}_{1}-r_{e} \cdot \mathrm{BPS}_{0}\right)}{\left(1+r_{e}\right)^{2}}+\frac{E_{-1}\left(\mathrm{EPS}_{2}-r_{e} \cdot \mathrm{BPS}_{1}\right)}{\left(1+r_{e}\right)^{3}}+\frac{E_{-1}\left(\mathrm{EPS}_{3}-r_{e} \cdot \mathrm{BPS}_{2}\right)}{\left(1+r_{e}\right)^{3} r_{e}}
$$

The expectation in (11) is conditioned on the absence (or no knowledge) of the acquisition. A comparison of equations (10) and (11) gives the impact of acquisition on the fundamental value per share of pre-acquisition acquirer shareholders as follows:

$$
\Delta V=V_{\text {post }}-V_{\text {pre }}
$$

If (12) is positive, then the takeover creates value for pre-acquisition acquirer shareholders.

\footnotetext{
23 Another problem is that in the year of the share issue, the capital charge is estimated based on the previous year's book value, when in fact it should be estimated relative to the previous year's book value plus the share issue value. Equation (10) also avoids this problem.

24 Another issue related to the method of financing is any change in capital structure around acquisition. If acquisitions are associated with an increase in leverage, this automatically causes an increase in the return on equity. However, with our fundamental value approach (in contrast to the ROE profitability approach described above), the cost of equity should increase to reflect the higher financial risk due to higher gearing.
} 
In order to make this measure comparable across firms, we calculate the percentage change in value for each acquirer as follows:

$$
\% \Delta V=\left(V_{\text {post }}-V_{\text {pre }}\right) / V_{\text {pre }}
$$

Using a percentage change measure allows us to compare firms with different valuations. The approach we adopt is broadly similar to that of Morton and Neill (2000) who examine the effect of corporate restructurings on fundamental value.

To control for performance changes that may have occurred in the absence of a takeover, such as macroeconomic and industry performance changes, we also estimate equation (13) for the acquirer industry and size-matched control firms described in Section 3 above. ${ }^{25,}{ }^{26}$ Comparing the acquirer with its matched control firm (rather than a mixture of acquirer and acquiree benchmarks), is the appropriate benchmark because we are interested in comparing the acquirer's performance with what would have happened in the absence of the takeover. In the case of non-horizontal acquisitions, the implicit assumption is that the acquirer would not have entered the target's industry in the absence of a takeover. ${ }^{27}$ Taking the difference in the percentage change in fundamental value between acquirers and control firms (the abnormal change in fundamental value) is analogous to estimating the abnormal share return over the announcement and post-acquisition periods. The abnormal change in fundamental value corresponds in theory to what the share return on the announcement of the acquisition would be if stock prices were efficient and there had been no prior anticipation of the acquisition.

\subsubsection{Estimation procedure for the RIV model}

25 Our matched control firm approach is an attempt to establish a counterfactual for the acquirer in the hypothetical situation where the acquisition does not take place. Our choice of counterfactual may be misspecified if acquirers differ from non-acquirers on factors other than size and industry, and these factors impact subsequent performance. Other studies are of course also subject to this potential misspecification. 26 Ritter and Warr (2002) argue that the RIV model tends to undervalue (overvalue) stocks in high (low) inflation periods. However, the matched control sample is aligned in calendar time, and mitigates this effect. 27 A similar implicit assumption is made in share return studies, which compare the acquirer with a matched control firm only. In diversifying acquisitions, if a higher price is paid for targets in well performing industries, controlling for acquiree industry performance incorrectly biases downwards the value impact of such acquisitions, since the fundamental value approach incorporates the acquisition price. In contrast, profitability studies do not incorporate the acquistion price and are concerned with whether the combined performance of the acquirer and acquiree improves following acquisition, and hence it is appropriate to employ a mixture of acquirer and acquiree benchmarks. 
We now turn to the practical implementation of the RIV model. The estimation techniques involved in its implementation require a number of assumptions. The techniques and assumptions that we employ are designed to be consistent with those used in other RIV studies. However, because the results may be sensitive to these techniques and assumptions, we later return to check the robustness of our results to these methods.

For our pre-acquisition valuation, we estimate future EPS by multiplying forecast ROE by predicted beginning of year book value per share in each future year. Our forecast of future ROE is the acquirer's average ROE in years -3 to -1 . Using pre-acquisition historical ROE to predict future ROE is consistent with our (and other) takeover profitability studies and previous applications of the residual income model (e.g. Frankel and Lee, 1998; Lee et al, 1999). ${ }^{28}$

We estimate book value per share for year 0 as book value per share in year -1 , to which we add forecast EPS in year 0 minus expected dividends per share in year 0 . We estimate book value per share for year 1 as estimated book value per share in year 0, to which we add forecast EPS less expected dividends per share in year 1, and so on for years 2 and 3.

We estimate future dividends per share as forecast EPS multiplied by estimated dividend payout ratio. Our estimated payout ratio is the average dividend payout ratio in years -3 to -1 . If any of the years -3 to -1 have negative earnings, we exclude these years from the calculation. We are unable to apply this method in two cases. If a firm has negative earnings in all three pre-acquisition years we are unable to estimate a payout ratio. If forecast EPS is negative we are unable to multiply by a payout ratio to estimate future dividends. In both cases we set future dividends to the level of dividends in year -1 .

For the cost of equity $\left(r_{e}\right)$ we calculate a firm-specific, time-varying discount rate using the Capital Asset Pricing Model (CAPM). For the CAPM discount rate, at the financial year end in years -1 to 3 ,

28 Alternatively, some previous RIV applications use analyst forecasts to predict EPS (Ang and Cheng, 2006; Dong et al., 2006). In the context of our study, we prefer to use prior ROE as a predictor for several reasons. Firstly, past ROE is used to predict future profitability in takeover profitability studies and hence its use facilitates comparison between the profitability and RIV methods, a key objective of our study. Secondly, analyst forecasts may already incorporate expectations of future acquisitions and hence bias any valuation impact towards zero (the share return methodology has the same drawback). Thirdly, analyst forecasts are biased and do not better predict future earnings any better than historic earning models (Capstaff et al., 1995; Bi and Gregory, 2008). Finally, these forecasts are not available for the entire sample period and would therefore reduce sample size. 
sample firm betas are calculated by Datastream (Datastream Item E058) using the previous 240 trading day share returns. We employ a market risk premium of 2.81 percent, estimated for the UK (over the years 1989-98) by Claus and Thomas (2001). The risk free rate is the UK 3-month Treasury bill rate at each financial year end. The cost of equity at year -1 is used for the pre-takeover valuation, whilst the average cost of equity over years 0 to 3 is used for the post-takeover valuation.

It is important to allow for a time-varying, firm-specific discount rate because acquiring firms experience a significant increase in leverage and the cost of equity following acquisition. Relative to control firms, the average acquiring firm's gearing ratio (long-term debt/long-term debt plus plus market capitalisation) increases by $3.34 \%$ following acquisition (year -1 compared to the average over years 0 to 3). This increase is statistically significant at the one percent level, and is consistent with previous studies (i.e. Ghosh and Jain, 2000). ${ }^{29}$ The acquirers' average beta increases from 0.72 to 0.78 following the acquisition, whereas the control firms' average beta is constant at 0.68 . In year -1 , the acquirers' average discount rate is 11.77 , increasing to an average of $11.94 \%$ over years 0 to 3 , whereas the control firms' average discount rate decreases from $11.66 \%$ to $11.64 \%$. The abnormal changes in beta and the cost of equity are significant at one percent.

If the terminal value is negative, we restrict it to be zero (for both the pre- and post-analysis), since over a long horizon, managers are not expected ex ante to invest in negative net present value projects (D'Mello and Shroff, 2000). If acquirers die within the four post-takeover years then the year of death becomes the final year of analysis and we estimate a terminal value using the same method used for surviving acquirers at the end of year $3 .^{30}$ In other words, we assume the final year earnings are earned in perpetuity. As with the profitability and share return results, each variable is winsorised at the $10^{\text {th }}$ and $90^{\text {th }}$ percentiles.

In contrast to profitability studies, our method calculates the change in fundamental value following acquisition and thus quantifies the total discounted value effect of takeover on the acquirer.

29 We also use a book value measure of gearing calculated as long-term debt divided by long-term debt plus book value of shareholders equity. The results are similar, showing an increase in leverage relative to control firms of $3.67 \%$, significant at one percent.

$30 \mathrm{We}$ could employ the last market value prior to death as the terminal value. We prefer not to rely on market values since the main source of death is acquisition and market values include bid premiums that may have little to do with fundamental value. We do, however, employ this method in our robustness tests below. 
In contrast to event studies, it measures the change in fundamental value rather than the change in market value. As such, it is less reliant on stock prices. However, it is not completely independent of market prices because the estimation of beta and hence the cost of equity relies on stock market efficiency.

\section{Empirical results}

In this section we report the empirical results. Section 5.1 describes the profitability results, Section 5.2 the share return results, and Section 5.3 the fundamental value results.

\subsection{Profitability results}

Table 2 below reports results using the traditional accounting performance measure. Panel A reports the pre-takeover performance. In year -3 , the combined acquirer-target performance is a significant $1.5 \%$ lower than control firms. In year -2 , the combined acquirer-target performance is no different from control firms, whilst in year -1 the performance is $1 \%$ higher (significant at ten percent). The average abnormal performance over years -3 to -1 is close to zero and statistically insignificant. Panel B reports the results for the post-takeover period. Over years 1 to 3, the abnormal performance is significantly positive in every year, and the average over years 1 to 3 is a significant 2.66\%. Panel C reports that the difference between the post- and pre-takeover abnormal performance is a significant $2.62 \%$, indicating that takeovers result in a significant improvement in return on equity. Panel D reports the results of a regression of post-takeover performance on pre-takeover performance. The intercept is a significant 2.61, similar to the abnormal change in Panel C. ${ }^{31}$ These results suggest that the combined performance of the acquirer and acquiree improves significantly following an acquisition.

\section{INSERT TABLE 2 ABOUT HERE}

We find no evidence that our results are sensitive to the methods we employ to deal with extreme observations. Employing five and one percent winsorisation levels makes no difference to our results

31 As pointed out in Section 4.1 above, the fact that the abnormal change in profitability is similar to the regression intercept indicates that for our sample the regression results are not biased by (unmatched) permanent drivers of profitability, a concern of Ghosh (2001). 
and using median figures and a Wilcoxon test gives a median abnormal change in profitability of $1.79 \%$ with a $Z$-value of -3.62 . Hence again, our key finding is unchanged.

The results indicate that takeovers significantly improve merging firms' return on equity. This improvement in performance is consistent with other UK studies for our time period that employ different measures of performance and sample selection procedures. Chatterjee and Meeks (1996) employ a profit before interest and tax measure and also find a significant improvement. Similarly, Manson et al. (1994), Manson et al. (2000), Powell and Stark (2005) and Cosh et al. (2006) employ an operating performance to market value measure and find evidence of significant improvements. ${ }^{32}$

Manson et al. (1994) and Manson et al. (2000) employ a different sample selection procedure both from our study and Chatterjee and Meeks (1996), Powell and Stark (2005) and Cosh et al. (2006) by only selecting merging firms that have full data available for the years surrounding the acquisition, and are not contaminated by other significant acquisitions in the two years surrounding the acquisition. The consistency in the results of these studies suggests that the finding of improved performance is robust to different sample selection procedures. However, for robustness, we carry out a similar sample selection procedure to Manson et al. (2000). First, we exclude sample acquisitions if they are preceded or followed by a significant acquisition within three calendar years of the acquisition year. We define a significant acquisition as one in which the transaction size is greater than one third of the acquirer's market value. This results in 44 acquisitions being excluded. ${ }^{33}$ Second, we exclude acquisitions if either the acquirer, target or control firm data are not available for the full three years before or after acquisition. This results in a further 90 acquisitions being excluded. The results for the remaining subsample of 169 acquisitions are similar to those for the full sample and hence our results are robust to these alternative sample selection requirements.

32 The improvement in return on equity may be due to an increase in leverage. However, we examine separately the 175 acquisitions where gearing increases relative to control firms and find that the improvement in return on equity is $2.10 \%$ and hence similar to that for the full sample. A further possible explanation for the profitability improvement is that acquirers wrote down fair values and immediately wrote off the inflated goodwill to reserves (Chatterjee and Meeks, 1996). However, Manson et al. (1994), Manson et al. (2000), Powell and Stark (2005) and Cosh et al. (2006) avoid this potential bias by using a range of denominators and still report significant performance improvements.

33 This approach has advantages and disadvantages. An advantage of an uncontaminated sample is that it focuses on a single event for each acquirer. A disadvantage is that this method is more likely to exclude frequent acquirers, and their performance may be different from other acquirers (see e.g. Conn et al., 2004). 
We also check the impact on the results of our treatment of goodwill, by removing from the analysis the 34 acquirers that capitalise goodwill. The change in profitability (as measured by the regression intercept) for this subsample of 269 acquisitions is $2.44 \%$, significant at one percent, and similar to the full sample results.

We conclude that overall, there is a significant improvement in merging firms' return on equity post-takeover.

\subsection{Share return results}

Table 3 reports abnormal share returns over the announcement period and the 36-month postacquisition period. Over the announcement month, the acquirer abnormal return is $-1.72 \%$, significant at one percent. ${ }^{34}$ Over the 36-month post-acquisition period, the buy-and-hold abnormal returns are $15.61 \%$, significant at one percent. The calendar time average monthly abnormal return is- 0.45 percent, and also statistically significant at the one percent level. We conclude that both at the time of the announcement and over the long run following the acquisition, acquirer share returns are significantly negative. These results are consistent with other studies of UK acquirers over this sample period such as Gregory (1997), Sudarsanam and Mahate (2003) and Conn et al. (2005).

\section{INSERT TABLE 3 ABOUT HERE}

As with the profitability tests, we check our results for the subsample of uncontaminated acquisitions (described in Section 5.1) with full data availability. Abnormal returns for this subsample are significantly negative in both the announcement month and over the long run, consistent with the full sample results. Again, as with the profitability tests, we find no evidence that our results are sensitive to the methods we employ to deal with extreme observations. Data based on five and one percent winsorisation levels also result in significantly negative returns over the announcement month and post-acquisition period. Furthermore, using median figures and a Wilcoxon test produces similar results. Although as noted in Section 4.2, the control firm approach we employ should eliminate the skewness bias, for robustness we also estimate a bootstrapped skewness-adjusted $t$-test for the buy-

34 Abnormal returns calculated over a three-day window starting one day prior to the announcement date, and relative to the market index, are a similar magnitude and significant at one percent. 
and-hold abnormal returns (Lyon et al., 1999). We use the hallt program in Stata, drawing 1,000 bootstrapped resamples of size 75 from the sample of 300 (following Lyon et al., 1999). This alternative $t$-test has a value of -3.91 and hence is very consistent with the $t$-test in Table 3 .

Our results so far are consistent with previous studies for our sample period: UK acquisitions have a significantly positive impact on profitability but a significantly negative impact on share returns. We now turn to the fundamental valuation analysis.

\subsection{Fundamental value results}

In this section we report the results of the RIV approach. Table 4 below reports the results of estimating equation (13) and the component parts for acquirers and control firms. Panel A reports the pre-takeover valuation, Panel B the post-takeover valuation, and Panel C the differences between the two. For each sample acquisition, the pre- and post-takeover value component parts and total values are normalised by the total pre-takeover value and multiplied by 100 . Thus, for each sample firm, the normalised total pre-takeover value takes the value of 100 . The differences in Panel $\mathrm{C}$ are the differences between each of these normalised values. Hence, the difference in total values is a difference in percentages and the differences in components show how this is divided among the individual components.

\section{INSERT TABLE 4 ABOUT HERE}

Panel A of Table 4 reports the components of pre-acquisition fundamental value of the acquirers and their control firms. This consists of forecast book value at year 0 , forecast dividends in year 0 , forecast residual income over years 1 to 2 , and forecast terminal value. These figures are $67.35,3.57$, 2.27 and 25.83 as proportions of pre-acquisition fundamental value. As a proportion of total preacquisition value, acquiring firms have lower book value but higher forecast residual income and terminal value.

Panel B of Table 4 reports the post-takeover fundamental value and its components for acquirers and control firms, as proportions of pre-acquisition value. This consists of book value in year 0 , realised dividends in year 0 , realised residual income in years 1 to 2 , forecast terminal value, and total value. Each of these values is higher than those forecast in Panel A, for both acquirers and control 
firms (the exception being book value for control firms). The components of post-acquisition value are not, however, significantly different between acquirers and control firms. The post-takeover value of acquirers of 120.14 is insignificantly different from the figure of 124.70 for control firms.

Panel C of Table 4 reports the differences between the figures in Panels A and B (the pre- and posttakeover valuations and their component parts) and significance levels. Acquirers experience a significant increase in book value per share in year 0 . Of the $20.14 \%$ increase in total value, $2.50 \%$ is due to an increase in book value. In contrast, control firms' book value is unchanged, and the abnormal change in book value is significantly positive. Dividends and residual income are also significantly higher than forecast for acquirers and control firms, but the differences between acquirers and control firms are not significant. Actual terminal value increases significantly compared to the forecast terminal value for both acquirers and control firms. However, the increase for acquirers is significantly lower than that for control firms.

The difference in total fundamental value for acquirers is $20.14 \%$ and $24.70 \%$ for control firms, both of which are significantly different from zero, but the difference is insignificant $(t=1.02)$. Therefore, our main conclusion is that acquisitions have a statistically insignificant effect on the acquirers' fundamental value.

\subsubsection{Checking the robustness of the RIV results}

In this section we carry out a range of checks to ensure that our main conclusion, that acquisitions result in an insignificant effect on fundamental value, is robust.

As Table 4 shows, the abnormal change in terminal value is significantly negative. The measure we use to calculate terminal value is EPS in year 3. This forecast is important because the terminal value is a large component of total fundamental value. If instead we use the average EPS over years 1 to 3 to forecast terminal value, the total abnormal change in fundamental value is an insignificant $-0.49 \%$. Therefore, although the change is higher, our key finding of an insignificant impact is unchanged. Furthermore, we believe year 3 earnings is the appropriate estimate of terminal value because post-acquisition ROE declines linearly over years 0 to 3 . For acquirers, abnormal ROE in year 3 is $13.57 \%$, compared to a pre-takeover abnormal ROE of $11.44 \%$, a difference that is not 
statistically significant. We believe it would be inappropriate to use a forecast of terminal value based on the higher values in the years immediately following the acquistion. As further evidence for this claim, average acquirer abnormal ROE over years 4 to 5 is $11.70 \%$, and thus lower still than ROE in year $3 .^{35}$

We also examine the impact of our assumptions regarding the payout ratio. Predicted fundamental value may differ from realised fundamental value if the actual payout ratio differs from the predicted payout ratio. If acquirers increase their dividend payments, there is less book value on which to generate future residual income. Additional tests show that acquirers increase their payout ratio in year 0 by $1.8 \%$, compared to a zero change for control firms. To check the robustness of our results, we calculate pre-takeover forecast book values using the average payout ratio in years 0 to 3 , rather than the payout ratio in year -1 . Our results are similar using this alternative method, with an insignificant abnormal change of $-3.71 \%(t=-0.85)$. For firms with negative earnings in all 3 preacquisition years $(-3,-2$ and -1$)$ or a forecast negative EPS, we assume that future dividends equal the level of dividends in year -1 . We test the sensitivity of our results to this assumption by rerunning our tests for the subsample of 287 acquisitions in which these conditions don't hold for both acquirers and control firms. Our results are unchanged for this subsample, which has an abnormal change in fundamental value of $-3.27(t=-0.76)$.

There are some potential concerns about the estimated cost of equity. First, betas estimated with daily data could be downward biased because of thin trading. ${ }^{36}$ However, the Datastream estimation technique controls for this problem and, furthermore, the same potential problem exists for control firms, and therefore any downward bias should also apply to control firms and therefore on average be controlled for. However, to control for this further, we exclude 74 acquisitions for which the acquiring firms have an average beta of less than 0.5. The fundamental value impact for the remaining 229 acquisitions is $-3.82(t=-0.73)$ which is similar to the impact for the full sample. In an additional test, we also estimate beta ourselves for acquirers and control firms by regressing monthly returns on

35 Given this finding, we repeated our profitability tests using five years pre- and post-takeover rather than three years. We still found evidence of a statistically significant improvement in profitability.

36 For acquiring firms, average beta over the pre- and post-acquisition periods is 0.76 , with a median of 0.79 , a minimum of 0.15 and a maximum of 1.26 . 
the UK stock market return for both the pre- and post-acquisition 36 month periods. Our results are very similar using this estimation of beta, with the abnormal change in fundamental value being -3.61 with a $t$-statistic of -0.76 . The second concern is that the results are biased upwards because increased post-acquistion leverage improves net income, and hence fundamental value, but is not reflected in a higher cost of capital because of a lack of association between gearing and beta. However, we find evidence of a strong association, with the correlation coefficient between the abnormal change in leverage and the abnormal change in the cost of equity being a significant 0.114 . Lastly, to test the sensitivity of our results to the increase in the cost of equity, we employ a constant discount rate based on the historical UK equity return of 10.2 percent (Dimson et al., 2000), for both acquirers and control firms. In this case the total abnormal change in fundamental value is an insignificant -2.93 percent, which is only marginally higher than the change in value using the time varying rate. Therefore, although the cost of equity increases following acquisition, this can at best only explain part of the difference between the profitability and RIV approaches.

As noted above, if acquirers or control firms die within the four post-takeover years then the year of death becomes the final year of analysis, for both the acquirer and the control firm, and we estimate a terminal value at that time using the EPS for the last year prior to death. We test the sensitivity of our results to this approach in two ways. First, we recalculate our results after excluding the 34 sample firms that die before the end of year 3. The abnormal change for this subsample is $-1.00 \%(t=$ -0.22 ) and hence similar to the results for the full sample. Second, we use the last market value of the firm prior to death for the 34 firms as an estimate of terminal value. In this case, the abnormal change in fundamental value is $2.93(t=0.63)$, and, although positive rather than negative, is still statistically insignificant and hence consistent with our key finding of an insignificant impact.

We examine whether our results are sensitive to the methods we employ to deal with extreme observations. First, we employ different winsorisation levels but this makes no difference to our results. Winsorising at $1 \%$ results in an abnormal change in total valuation of $-5.25(t=-0.80)$, whilst winsorising at $5 \%$ results in a change of $-3.97(t=-0.76)$. Second, we use median figures and a Wilcoxon test. The median abnormal change in total valuations is 0.76 with a $Z$-value of 0.191 . Hence again, this finding is consistent with our key finding of an insignificant impact. 
A potential problem in comparing ex-post and ex-ante valuations is that of share issues occuring during the ex-post period (Ohlson, 2005). If share prices after year 0 differ from average historical issue prices, then the residual income model incorporates a different capital charge without an offseting different book value per share. A different potential problem with a similar effect that may have occurred with UK acquirers over our sample period, is the revaluation of intangible assets to replenish balance sheets depleted by goodwill write-offs (Higson, 1998; O'Hanlon and Pope, 1999; Gregory, 2000). We check the robustness of our findings to both problems by estimating book value per share in each year subsequent to year 0 as book value in year 0 plus cumulative earnings per share minus cumulative dividends per share since year 0 (following Penman and Sougiannis, 1998). This book value is unaffected by subsequent share issues or revaluations after year 0 . The abnormal change in fundamental value using this method is an insignificant -5.19 percent $(t=-1.13)$. We are therefore confident that our results are robust to these potential biases. ${ }^{37}$

As with the profitability and share return tests, we check our results for the subsample of acquisitions with full data availability and that are not contaminated by other acquisitions. Again, our results are robust. The abnormal fundamental value change for this sample of 169 acquisitions is an insignificant $1.41 \%(t=0.25)$ and thus similar to the full sample of a statistically insignificant impact.

Finally, as with the profitability study, we carry out robustness checks of the way in which our fundamental approach incorporates goodwill. We noted in Section 4 that the only issue that arises with acquisition accounting is that the forecast horizon should extend as far as the amortisation period, to ensure that the predicted earnings per share used in the terminal value is free of the amortisation charge. We have not done this in our analysis both because it requires knowledge of the length of the amortisation period and because, for our sample, at most 34 acquirers are potentially affected. The abnormal change in fundamental value for the 269 acquirers that do not potentially suffer this

\footnotetext{
37 Share issues and violations may distort pre-acquisition ROE which we use to forecast post-acquisition EPS. To address this concern, rather than using historical ROE to forecast future EPS, we forecast post-acquisition year 0 EPS as year -1 EPS multiplied by one plus the average percentage EPS growth over the three preacquisition years. We then forecast year 1 EPS as forecast year 0 EPS multiplied by one plus the same EPS growth rate, and so on for years 2 and 3.The abnormal change in fundamental value using this method is -0.75 (tstatistic -0.16) and hence very similar to using historical ROE.
} 
downward bias is an insignificant $-7.17(t=-1.50)$. Therefore, there is no evidence that our results are biased downwards by this omission.

In this section we report on a wide range of robustness tests and are confident that our main conclusion, that acquisitions have a small and insignificant effect on fundamental value, is robust. This result stands in contrast to both the profitability results, which are significantly positive, and the share return effects, which are significantly negative. In seeking to reconcile the RIV results with the profitability results, a key difference in the methodologies is that the profitability approach measures ROE, whereas the RIV approach measures post-acquisition book value per share and EPS. Despite the fact that ROE improves (as shown in Section 5.1), we find (in additional tests) that acquirers' EPS decreases relative to control firms. The percentage change in pre- and post-acquisition EPS for acquiring firms relative to control firms is $-9.00 \%(t=-1.40)$. This appears to be an important reason why the profitability results differ from the RIV results. In trying to reconcile the RIV results with the return results, we note above that one problem with the share return methodology is that acquirers may be overvalued at the time of acquisition, and that the share price could fall following acquisition because of this over-valuation regardless of the impact on fundamental value. To consider this further, we now examine the performance impacts of a subset of acquisitions for which such overvaluation appears likely.

\subsubsection{The impact of acquirer over-valuation and equity bids}

Our RIV methodology incorporates the benefit derived by acquirer shareholders from using overvalued shares for the acquisition, and hence allows us to examine whether cash bids and equity bids have different impacts on fundamental value. Shleifer and Vishny (2003) argue that this is an important motivation for acquisitions and recent evidence for both the US (Ang and Cheng, 2006, and Dong et al., 2006) and the UK (Bi and Gregory, 2008) suggests that acquirers using equity are overvalued at the time of acquisition.

To examine whether there is any evidence of acquirer overvaluation in our sample, we divide the fundamental pre-takeover valuation by the share price at announcement for both acquirers and control firms. The value for acquirers is 0.95 , whilst for control firms it is 0.97 and the difference is not 
significant. Since any equity over-valuation effect is presumably limited to cases where the firm issues equity, we restrict the same analysis to 'equity' bids, as defined in Table 1. In this case the value for acquirers is 0.90 whilst that for control firms is 0.97 . The difference is insignificant using a parametric test $(t=-1.50)$, but is significant using a Wilcoxon Test $(z=-2.23)$. Hence we find some evidence that acquirers using equity are overvalued. ${ }^{38}$

Next, we examine whether the impact on fundamental value differs by method of payment and overvaluation. The impact of cash acquisitions (65) on fundamental value is insignificantly positive (11.01\%), whilst the impact of equity acquisitions (173) is insignificantly negative $(-2.40 \%)$. The difference in the abnormal returns between the two types of acquisition is insignificant. ${ }^{39}$ We further examine the impact on the subsample of equity bidders that are overvalued prior to acquisition (101) relative to control firms. In this case the impact on fundamental value is a significant $39.50(t=5.37)$. Therefore, we find strong evidence that acquirers that are overvalued and use equity to pay for the acquisition create significant fundamental value for their shareholders. In stark contrast, the share returns for this subsample of 101 firms is worse than for the sample as a whole, with announcement returns of $-2.52 \%$ and long run buy-and-hold returns of $-28.02 \%$. Therefore, the equity overvaluation effect may go some way to explaining the negative impact of takeover on share returns and the difference between the impact of acquisitions on share returns and on fundamental value.

\section{Conclusions}

In this paper we develop a methodology for evaluating takeover success by measuring whether the fundamental value of acquirers is greater after an acquisition. Our methodology employs the residual income approach to fundamental valuation, and differs significantly from profitability and share return studies. Profitability studies do not quantify the total discounted value effect of takeovers because they do not account for the cost of capital, the timing of profits earned, or the amount paid for the target

\footnotetext{
38 Previous studies for the US (Ang and Cheng, 2005; Dong et al., 2006) and the UK (Bi and Gregory, 2008), find stronger evidence of acquirer overvaluation. However, the difference appears to be driven by the difference in sample time periods. For example, Dong et al. (2006) report an average V/P (RIV value / share price) of 0.77 over 1978-2000. However, the average V/P of Dong et al. over our sample time period (1985-96) (estimated from their Table 2) is much higher at 0.89 and very close to our value of 0.95 .

39 The impact of mixed (equity plus cash) acquisitions on fundamental value is $-17.15(t=-1.43)$ whilst the impact of other payment methods on fundamental value is $-38.91(t=-2.48)$.
} 
company. Share return studies on the other hand, reflect many factors, such as anticipation of the acquisition or initial market mispricing at announcement, and not necessarily the fundamental impact of acquisitions. The fundamental value approach that we develop quantifies the total discounted value effect of takeovers and is less reliant upon stock market prices. As such, it has advantages over both the profitability and share return approaches in measuring the impact of acquisition on fundamental value. However, our approach shares some of the same weaknesses and requires a number of important assumptions.

We test all three methodologies on a comprehensive sample of 303 takeovers involving UK public companies. These takeovers result in a significant improvement in the profitability of the merging companies. However, acquirer share returns over both the announcement and long run post-takeover periods are significantly negative. Both sets of findings are consistent with other UK studies for our sample time period. Using our fundamental valuation approach, we find that acquisitions have a small and insignificant effect on fundamental value, relative to control firms. Therefore, the results found using a fundamental value approach differ significantly from the profitability and share return approaches.

Our fundamental value results are subject to a number of qualifications and potential weaknesses as pointed out above. However, if we nevertheless accept them as accurately estimating an insignificant effect on fundamental value, then what do the results imply about the proper interpretation of the profitability and return studies?

Firstly, with regard to profitability, although this improves for the combined assets postacquisition, a combination of factors would appear to result in this improvement not being reflected in an increase in fundamental value; although return on equity increases after acquisition, earnings per share does not; the improved profitability declines over the post-acquisition period, resulting in a relatively low terminal value; acquirer leverage increases following acquisition causing an increase in the cost of equity, hence reducing the present value of the increased profits; and the cost of the acquisition is fully incorporated, unlike with the profitability measure due to acquirers writing off goodwill over our sample period. 
Secondly, with regard to the return studies, our findings clearly refute the argument that the negative share returns experienced by acquirer firms reflect the stock market belatedly reacting to the impact of acquisitions on acquirers' fundamental values. Furthermore, we find that acquirers are somewhat over-valued by the stock market at announcement, and that share returns are even more negative for overvalued acquirers, despite the fact that these acquirers experience a significant increase in fundamental value. Therefore, the equity overvaluation effect may go some way to explaining the negative impact of takeover on share returns and the difference between the impact of acquisitions on share returns and on fundamental value.

Overall, we conclude that it is potentially misleading to draw conclusions on the fundamental value impact of takeover from either profitability or share return studies. However, empirical application of the residual income model employed here requires a number of important assumptions. We have carried out a number of additional tests to check the robustness of our key findings. However, further research could examine whether our methodology stands the test of further exploration of this or more recent data. One worthwhile approach would be to use analyst forecasts (rather than historical earnings) to predict future (post-acquisition) earnings per share, which would avoid any problems of dirty surplus accounting in the pre-acquisition period. Additionally, future research could extend the analysis to a more recent sample of acquisitions, to ensure that our results are robust across different time periods. 
Table 1

Transaction descriptives for the acquisition sample

$\%$ of acquisitions by method of payment

Cash

Equity

57.10

Mixed

Other

Average bid premium (\%)

36.80

Average relative size (\%)

$\%$ of horizontal acquisitions

34.98

\section{Notes:}

This table reports summary statistics for a sample of 303 acquisitions of UK public targets by UK public firms between January 1985 and December 1996, where the acquirer and target are included on the Datastream Database. Horizontal acquisitions are defined as those in which the acquirer and target share the same primary Datastream Industrial Classification level four. 'Cash' offers include pure cash offers (13.53\%) and cash offers with a loan note alternative (7.92\%). 'Equity' offers include pure equity offers $(21.78 \%$ ) and equity offers with a cash alternative (35.31\%). 'Mixed' includes offers that include a combination of cash and equity. 'Other' includes the following payment methods: All cash or cash plus equity (2.97\%), all equity or cash plus equity $(2.31 \%)$, convertible preference shares with a cash alternative $(0.33 \%)$, equity or debt or cash $(0.99 \%)$, all cash or cash plus equity with a loan note alternative $(0.66 \%)$, pure debt $(0.33 \%)$, other $(0.99 \%)$. The bid premium is estimated as the difference between the transaction value and the market value of the target one-month prior to the acquisition announcement. Relative size is measured as the bid value divided by the market value of the acquirer at announcement. 
Table 2

The effect of takeover on profitability

\begin{tabular}{|c|c|c|c|c|c|c|c|}
\hline \multirow[t]{2}{*}{ Year relative to takeover } & \multirow[t]{2}{*}{ No. } & \multicolumn{6}{|c|}{$\operatorname{ROE}(\%)$} \\
\hline & & $\begin{array}{l}\text { Sample } \\
\text { firms }\end{array}$ & t-test & $\begin{array}{l}\text { Control } \\
\text { firms }\end{array}$ & t-test & Abnorma & $t$-test \\
\hline \multicolumn{8}{|c|}{ Panel A: Pre-takeover profitability } \\
\hline-3 & 219 & 13.19 & & 14.67 & & $-1.47^{\mathrm{b}}$ & $(-2.56)$ \\
\hline-2 & 265 & 15.43 & & 15.65 & & -0.21 & $(-0.36)$ \\
\hline-1 & 303 & 17.17 & & 16.18 & & $0.99^{\mathrm{c}}$ & $(1.72)$ \\
\hline Mean -3 to -1 & 303 & 15.88 & & 15.84 & & 0.04 & $(0.07)$ \\
\hline
\end{tabular}

Panel B: Post-takeover profitability

$\begin{array}{llllll}0 & 303 & 21.50 & 16.25 & 5.26^{\mathrm{a}} & (7.77) \\ 1 & 303 & 19.96 & 16.25 & 3.71^{\mathrm{a}} & (5.69) \\ 2 & 286 & 18.05 & 15.72 & 2.34^{\mathrm{a}} & (3.51) \\ 3 & 269 & 17.24 & 15.34 & 1.90^{\mathrm{a}} & (2.80) \\ \text { Mean 1 to 3 } & 303 & 18.60 & 15.94 & 2.66^{\mathrm{a}} & (4.56)\end{array}$

Panel C: Difference between pre-takeover and post-takeover profitability

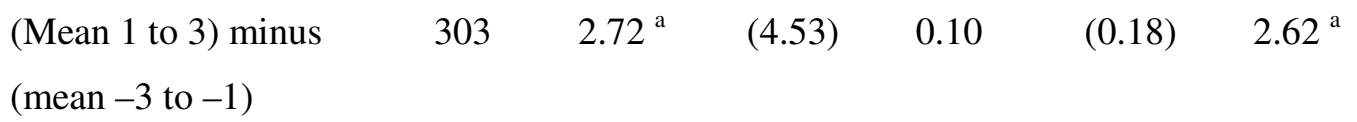

Panel D: Results of abnormal post-takeover profitability (mean 1 to 3) regressed on abnormal pre-takeover profitability (mean -3 to -1$)$

\begin{tabular}{llllll} 
A & $t$-stat & B & $t$-stat & $\mathrm{R}^{2}$ & No. \\
\hline $2.61^{\text {a }}$ & $(4.24)$ & $29.68^{\text {a }}$ & $(4.57)$ & 0.07 & 303 \\
\hline
\end{tabular}

Notes:

This table reports the impact of takeover on profitability. Our measure of profitability is return on equity (ROE), defined as net income divided by shareholder funds. Panel A reports profitability over each of the three pretakeover years, and the average for all three years. For sample firms, the return in years -3 to -1 is the weighted average of bidder and target, with the weights being the equity book values of the two firms in year -1 . For each acquisition, a non-merging control firm is selected for both the target and acquirer, matched on industry and size in year -1 . Control firm profitability is the weighted average profitability of the two control firms, weighted by the book equity values of the bidder and target in year -1 . Abnormal performance is measured relative to these control firms. Panel B reports profitability over each of the four post-takeover years (year 0 is the year of consolidation), and the average for years 1 to 3 . For years 0 to 3 the sample firm return is the acquirer return. Panel C reports the simple difference between the post-takeover profitability measured over years 1 to 3 , and the pre-takeover profitability measured over years -3 to -1 . Panel D reports the results of an OLS regression of abnormal post-takeover performance on abnormal pre-takeover performance. Each of the annual profitability measures for both the sample firms and control firms are winsorised at the ten percent level. ${ }^{\mathrm{a}, \mathrm{b}, \mathrm{c}}$ indicate statistical significance at the 1,5 and 10 percent levels respectively, using a two-tailed test. 
Table 3

The effect of takeover on the announcement and long-run share returns of the acquirer

\begin{tabular}{llllll}
\hline Time period & No. & \multicolumn{4}{c}{ Share returns (\%) } \\
\hline & & Acquirer & Control firm & Abnormal & t-test \\
\cline { 3 - 6 } Announcement month & 300 & 1.50 & 3.22 & $-1.72^{\text {a }}$ & $(-3.45)$ \\
Post-acquisition buy-and-hold & 300 & 27.68 & 43.29 & $-15.61^{\text {a }}$ & $(-3.42)$ \\
Post-acquisition calendar time & 300 & 0.91 & 1.35 & $-0.45^{\text {a }}$ & $(-3.07)$ \\
\hline
\end{tabular}

Notes:

This table reports the share returns of the acquirer over the announcement month and the long run postacquisition period following acquisition completion. For each acquirer, a non-merging control firm is matched on industry and size in the year prior to the acquisition (year -1). Abnormal returns over both periods are measured relative to this control firm. The announcement month return is the average monthly return over the calendar month in which the acquisition is announced. The post-acquisition buy-and-hold return is the buy-andhold return over the 36-month period following the end of the announcement period (the end of the completion month). The $t$-statistic for the post-acquisition buy-and-hold return is adjusted for cross-sectional dependence as described in the text. The raw announcement month and buy-and-hold returns for both acquirers and control firms are winsorised at the ten percent level. Calendar months with less than ten observations have been excluded from the analysis. ${ }^{\text {a b, } c}$ indicate statistical significance at 1,5 and 10 percent respectively, using a twotailed test. 
Table 4

The effect of acquisition on the fundamental value of acquirers

\begin{tabular}{llllll}
\hline Variable & \multicolumn{5}{l}{ Fundamental value } \\
\hline & Acquirer & $\begin{array}{l}\text { t-test } \\
\text { Pantrol }\end{array}$ & $\begin{array}{l}\text { Contest } \\
\text { firm }\end{array}$ & Abnormal & t-test \\
\cline { 2 - 5 } Book value in year 0 & 67.35 & 72.94 & $-5.59^{\text {a }}$ & $(-2.80)$ \\
Dividends in year 0 & 3.57 & 3.59 & -0.03 & $(-0.21)$ \\
Residual income in years 1 to 2 & 2.27 & 0.92 & $1.34^{\text {a }}$ & $(2.62)$ \\
Terminal value & 25.83 & 21.95 & $3.88^{\text {a }}$ & $(2.44)$ \\
\hline Total value & 100.00 & 100.00 & 0.00 & \\
\hline Panel B: Post-acquisition value & & & & \\
Book value in year 0 & 69.85 & 71.63 & -1.78 & $(-0.73)$ \\
Dividends in year 0 & 3.87 & 3.82 & 0.06 & $(0.38)$ \\
Residual income in years 1 to 2 & 3.91 & 3.50 & 0.41 & $(0.70)$ \\
Terminal value & 39.05 & 41.43 & -2.38 & $(-0.92)$ \\
\hline Total value & 120.14 & 124.70 & -4.55 & $(-1.02)$ \\
\hline
\end{tabular}

\begin{tabular}{lllllll}
\hline $\begin{array}{l}\text { Panel C: Difference between post- } \\
\text { and pre-acquisition values }\end{array}$ & & & & & & \\
Book value & $2.50^{\mathrm{B}}$ & $(2.05)$ & -1.30 & $(-1.49)$ & $3.81^{\mathrm{b}}$ & $(2.54)$ \\
Dividends & $0.31^{\mathrm{B}}$ & $(3.34)$ & $0.22^{\mathrm{a}}$ & $(3.00)$ & 0.08 & $(0.72)$ \\
Residual income in years 1 to 2 & $1.65^{\mathrm{a}}$ & $(2.98)$ & $2.58^{\mathrm{a}}$ & $(4.02)$ & -0.93 & $(-1.30)$ \\
Terminal value & $13.22^{\mathrm{a}}$ & $(4.88)$ & $19.49^{\mathrm{a}}$ & $(7.12)$ & $-6.27^{\mathrm{c}}$ & $(-1.92)$ \\
\hline Total value & $20.14^{\mathrm{a}}$ & $(5.57)$ & $24.70^{\mathrm{a}}$ & $(6.96)$ & -4.55 & $(-1.02)$ \\
\hline
\end{tabular}

Notes:

This table reports the fundamental value of the sample acquirers before and after acquisition. Each acquirer is matched with a non-merging control firm on industry and size in the year before the acquisition (year -1). Abnormal fundamental value is measured relative to the control firm. Panel A reports the components of preacquisition fundamental value of the acquirers and their control firms. This consists of book value in year -1 , forecast dividends in year 0 , forecast residual income over years 1 to 2 , and forecast terminal value. Panel $\mathrm{B}$ reports the post-takeover fundamental value and its components for acquirers and control firms. This consists of book value in year 0 , realised dividends in year 0 , residual income in years 1 to 2 , and forecast terminal value. Panel $\mathrm{C}$ reports the difference between the total post- and pre-takeover values and their components. For each sample acquisition, the pre- and post-takeover value component parts and total values are normalised by the total pre-takeover value, and multiplied by 100 . Thus, for each sample firm, the normalised total pre-takeover value takes the value of 100. The differences in Panel $\mathrm{C}$ are the differences between each of these normalised values. Hence, the difference in total values is a difference in percentages and the differences in components show how this is divided among the individual components. The figures reported are means, with $t$-values in parentheses. All of the raw figures (both total value and component parts, columns 1-2 and Panels A-B) are winsorised at the ten percent level.Because the component parts are winsorised as well as the total values, the total values are not the precise sum of the component parts. ${ }^{\mathrm{a}, \mathrm{b}, \mathrm{c}}$ indicate statistical significance at 1,5 and 10 percent using a twotailed test. 


\section{References}

Alberts, W.W. \& Varaiya, N.P. (1989). 'Assessing the Profitability of Growth by Acquisition: A 'Premium Recapture' Approach'. International Journal of Industrial Organisation, 7: 133-149.

Andrade, G. \& Stafford, E. (2004). 'Investigating the Economic Role of Mergers'. Journal of Corporate Finance, 10: 1-36.

Ang, J.S. \& Cheng, Y. (2006). 'Direct Evidence on the Market-Driven Acquisitions Theory'. Journal of Financial Research, 29: 199-216.

Barber, B. \& Lyon, D. (1996). 'Detecting Abnormal Operating Performance: The Empirical Power and Specification of Test Statistics'. Journal of Financial Economics, 41: 359-399.

Barber, B.M. \& Lyon J.D. (1997). 'Detecting Long-Run Abnormal Stock Returns: The Empirical Power and Specification of Test Statistics'. Journal of Financial Economics, 43: 341-372.

Bhagat, S., Dong, M. Hirshleifer, D. \& Noah, R. (2005). 'Do Tender Offers Create Value? New Methods and Evidence'. Journal of Financial Economics, 76: 3-60.

Bi, X.G. \& Gregory, A. (2008). 'Stock Market Driven Acquisitions versus the Q Theory of Takeovers - The UK Evidence'. Working Paper University of Exeter.

Bruner, R.F. (2002). 'Does M\&A Pay? A Survey of Evidence for the Decision-Maker'. Journal of Applied Finance, 2: 48-68.

Capstaff, J., Paudyal, K. \& Rees, W. (1995). 'The Accuracy and Rationality of Earnings Forecasts by UK Analysts'. Journal of Business Finance and Accounting, 22: 67-86.

Chatterjee, R. \& Meeks, G. (1996). 'The Financial Effects of Takeover: Accounting Rates of Return and Accounting Regulation'. Journal of Business Finance \& Accounting, 23: 851-868.

Claus, J. \& Thomas, J. K. (2001). 'Equity Premia as Low as Three Percent? Evidence from Analysts' Earnings Forecasts for Domestic and International Stock Markets'. Journal of Finance, 56: 16291666.

Conn, R.L., Cosh, A., Guest, P.M. \& Hughes, A. (2004). 'Why must all Good Things come to an End? The Performance of Multiple Acquirers'. In D.H. Nagao (ed.), Proceedings of the Sixty-third Annual Meeting of the Academy of Management. 
Conn, R.L., Cosh, A., Guest, P.M. \& Hughes, A. (2005). 'The Impact on UK Acquirers of Domestic, Cross-Border, Public and Private Acquisitions'. Journal of Business Finance \& Accounting, 32: 815-870.

Cosh, A., Guest, P.M. \& Hughes, A. (2006). 'Board Shareownership and Takeover Performance'. Journal of Business Finance \& Accounting, 33: 459-510.

Cosh, A., Hughes, A. \& Singh, A. (1980). 'The Causes and Effect of Takeovers in the United Kingdom: An Empirical Investigation for the Late 1960s at the Microeconomic Level' in D.C. Mueller (ed.), The Determinants and Effects of Merger: An International Comparison (Gunn \& Hain).

Dimson, E., Marsh, P. \& Staunton, M. (2000). 'Risk and Return in the $20^{\text {th }}$ and $21^{\text {st }}$ Centuries'. Business Strategy Review, 11: 1-18.

D’Mello, R. \& Shroff, P.K. (2000). 'Equity Undervaluation and Decisions Related to Repurchase Tender Offers: An Empirical Investigation’. Journal of Finance, 55: 2399-2424.

Dong, M., Hirshleifer, D., Richardson, S. \& Teoh, S.H. (2006). 'Does Investor Misvaluation Drive the Takeover Market?'. Journal of Finance, 61: 725-762.

Edwards, E.O. \& Bell, P.W. (1961). The Theory and Measurement of Business Income (Berkeley: University of California Press).

Fama, E.F. (1998). 'Market Efficiency, Long-Run Returns, and Behavioral Finance'. Journal of Financial Economics, 49: 283-306.

Feltham, G. \& Ohlson, J.A. (1995). 'Valuation and Clean Surplus Accounting for Operating and Financial Activities'. Contemporary Accounting Research, 11: 689-731.

Frankel, R. \& Lee, C.M. (1998). 'Accounting Valuation, Market Expectation, and Cross-Sectional Stock Returns'. Journal of Accounting and Economics, 25: 283-319.

Ghosh, A. \& Jain, P.C. (2000). 'Financial Leverage Changes associated with Corporate Mergers'. Journal of Corporate Finance, 6: 377-402.

Ghosh, A. (2001). 'Does Operating Performances really improve following Corporate Acquisitions?'. Journal of Corporate Finance, 7: 151-178. 
Graham, J.R. \& Harvey, C.R. (2001). 'The Theory and Practice of Corporate Finance: Evidence from the Field'. Journal of Financial Economics, 60: 187-243.

Gregory, A. (1997). 'An Examination of the Long Run Performance of UK Acquiring Firms'. Journal of Business Finance and Accounting, 24: 971-1002.

Gregory, A. (2000). 'Motives underlying the Method of Payment by UK Acquirers: the Influence of Goodwill'. Accounting and Business Research, 30: 227-240.

Hietala, P., Kaplan, S.N. \& Robinson, D.T. (2003). 'What is the Price of Hubris? Using Takeover Battles to Infer Overpayments and Synergies'. Financial Management, 32: 5-31.

Higson, C. (1998). ‘Goodwill’. British Accounting Review, 30: 141-158.

Hughes, A. (1989). 'Mergers and Economic Performance in the UK: A Survey of the Empirical Evidence 1950-1990' in M. Bishop and J. Kay (eds.), European Mergers and Merger Policy (Oxford: Oxford University Press).

Jaffe, J.F. (1974). ‘Special Information and Insider Trading'. Journal of Business, 47: 305-360.

Jensen, M. \& Ruback, R. (1983). 'The Market for Corporate Control: The Scientific Evidence'. Journal of Financial Economics, 11: 5-50.

Lee, C.M. (1999). 'Accounting-Based Valuation: Impact on Business Practices and Research'. Accounting Horizons, 13: 413-425.

Lee, C.M., Myers, J. \& Swaminathan, B. (1999). 'What is the Intrinsic Value of the Dow?'. Journal of Finance, 54: 1693-1741.

Lyon J.D., Barber, B.M. \& Tsai, C. (1999). 'Improved Methods for Tests of Long-Run Abnormal Stock Returns'. Journal of Finance, 54: 165-201.

Mandelker, G. (1974). 'Risk and Return: The Case of Merging Firms'. Journal of Financial Economics, 1: 303-335.

Manson, S., Stark, A.W. \& Thomas, H.M. (1994). A Cash Flow Analysis of the Operational Gains from Take-overs, Certified Research Report 35 (London: Certified Accountants Education Trust).

Manson, S., Powell, R., Stark, A.W. \& Thomas, H.M. (2000). 'Identifying the Sources of Gains from Takeovers'. Accounting Forum, 24: 319-343. 
Martynova, M. \& Renneboog, L. (2008). 'A Century of Corporate Takeovers: What have we learned and where do we stand?'. Journal of Banking and Finance, 32: 2148-2177.

Meeks, G. (1977). Disappointing Marriage: A Study of the Gains from Merger (Cambridge: Cambridge University Press).

Mitchell, M.L. \& Mulherin, J. (1996). 'The Impact of Industry Shocks on Takeover and Restructuring Activity'. Journal of Financial Economics, 41: 193-229.

Mitchell, M.L. \& Stafford, E. (2000). 'Managerial Decisions and Long-Term Stock Price Performance'. Journal of Business, 73: 287-329.

Morton, R.M. \& Neill, J.D. (2000). 'The Relation between Market Prices and an Analyst-Based Fundamental Value Surrounding a Corporate Restructuring'. Journal of Accounting and Finance Research, 8.

Ohlson, J.A. (1995). 'Earnings, Book Values, and Dividends in Security Valuations'. Contemporary Accounting Research, 11: 661-687.

Ohlson, J.A. (2005). 'On Accounting-based Valuation Formulae'. Review of Accounting Studies, 10: 323-347.

O’Hanlon, J.F. \& Pope, P.F. (1999). ‘The Value-Relevance of UK Dirty Surplus Accounting Flows'. British Accounting Review, 32: 459-482.

Peasnell, K. (1982). 'Some Formal Connections between Economic Values and Yields and Accounting Numbers'. Journal of Business Finance and Accounting, 9: 361-381

Penman, S.H. \& Sougiannis, T. (1998). 'A Comparison of Dividend, Cash Flow, and Earnings Approaches to Equity Valuation'. Contemporary Accounting Research, 15: 343-383.

Penman, S.H. (2001, 2004, 2007). Financial Statement Analysis \& Security Valuation (New York: McGraw Hill). First, Second, and Third Editions respectively.

Powell, R. \& Stark, A. (2005). 'Does Operating Performance Increase Post-Takeover for UK Takeovers? A Comparison of Performance Measures and Benchmarks'. Journal of Corporate Finance, 11: 293-317.

Powell, R. \& Yawson, A. (2005). 'Industry Aspects of Takeovers and Divestitures: Evidence from the UK'. Journal of Banking and Finance, 29: 3015-3040. 
Preinreich, G.A.D. (1938). 'Annual Survey of Economic Theory: The Theory of Depreciation'. Econometrica, 6: 219-241.

Ritter, R.J. \& Warr, R.S. (2002). 'The Decline of Inflation and the Bull Market of 1982 to 1997'. Journal of Financial and Quantitative Analysis, 37: 29-61.

Shleifer, A. \& Vishny, R. (2003). 'Stock Market Driven Acquisitions'. Journal of Financial Economics, 70: 295-311.

Stark, A.W. (1986). 'More on the Discounting of Residual Income Streams'. Abacus, 22: 52-67.

Sudarsanam, S. \& Mahate, A.A. (2003). 'Glamour Acquirers, Method of Payment and PostAcquisition Performance: The UK Evidence'. Journal of Business Finance \& Accounting, 30: 299-341.

Tuch, C. \& O'Sullivan, N. (2007). 'The Impact of Acquisitions on Firm Performance: A Review of the Evidence'. International Journal of Management Reviews, 9: 141- 170. 